\title{
Leachate characterization of active and closed dump sites in Port Harcourt metropolis, Nigeria
}

\author{
Iwekumo Ebibofe AGBOZU $^{1^{*}}$ and Michael NWOSISI ${ }^{2}$ \\ ${ }^{I}$ Department of Environmental Science, Federal University of Petroleum Resources, Effurun, PMB 1221, \\ Effurun, Nigeria. \\ ${ }^{2}$ Institute of Natural Resources, Environment and Sustainable Development, University of Port Harcourt, \\ Nigeria. \\ "Corresponding author; E-mail: iwekumo@yahoo.co.uk, Tel: +234-8035426708
}

\begin{abstract}
Leachates are said to have the capacity of polluting environmental media such as air, soil, surface and ground water. The knowledge of the composition of leachates is important to determine the dump sites that require immediate remediation attention and their effective treatment approach. This study characterizes the leachate quality of both active and closed dump sites in Port Harcourt City. Leachates were sampled from the base of the dum psites and analysed, $\mathrm{pH}$, dissolved oxygen (DO), electrical conductivity and total dissolved solids were determined on the samples in-situ. While chloride, sulphate, phosphate, chemical oxygen demand (COD), biochemical oxygen demand (BOD), lead, zinc, iron, chromium, copper, cadmium and nickel were analyzed in the laboratory. The sample locations were Nkpolu Junction along East-West Road (LS1), Chindah Borrow Pit, off Chindah Road, Mile 4(LS2) and Rumuepirikom Community, off Iwofe Road (LS3). Locations $1 \& 3$ are closed dump sites, while location 2 is an active dump site. The mean pollution indices for Locations $1,2 \& 3$ include; $\mathrm{pH}$ (7.96, 6.55 \& 7.43), BOD (mg/l) (1.24, $5.95 \& 2.94), \mathrm{COD}(\mathrm{mg} / \mathrm{l})(3.10,14.87 \& 7.35)$ and DO (mg/l) $(2.3,0.85 \& 0.56)$. Heavy metals analyses reveals Iron $(\mathrm{mg} / \mathrm{l})$ having the highest concentration $(0.176,0.461 \& 0.253$ for LS1, LS2 \& LS3 respectively) which exceeds the maximum contaminant levels of $0.05 \mathrm{mg} / \mathrm{l}$ prescribed by the Federal Ministry of Environment, which is a regulatory body in Nigeria. The ratio of $\mathrm{BOD}_{5} / \mathrm{COD}$ was less than 0.5 for leachates from all sample locations, an indication of dump site stabilization while the $\mathrm{pH}$ values indicated that all sample locations in terms of age of the dump site vary partially from being young to mature in age. The study recommends continuous monitoring of leachates for the active dump site, as the concentration of individual parameters that make up the leachate is quite variable.
\end{abstract}

(C) 2015 International Formulae Group. All rights reserved.

Keywords: Leachate quality, dump sites, remediation, $\mathrm{BOD}_{5} / \mathrm{COD}$ ratio.

\section{INTRODUCTION}

Solid waste management is a serious problem in Nigeria, since there are no standard engineered sanitary landfills in the country at the moment. The absence of proper engineered sanitary landfills for disposal of wastes by the local and state governments has given room for the proliferations of open dumps that are scattered in every nook and cranny of the country. These scattered refuse dump sites found everywhere have become an eyesore to first time visitors to most cities in 
Nigeria including Port Harcourt City, the hub of Nigeria's oil and gas industry.

Although solid waste is an asset when properly managed, its volume has continued to increase tremendously in recent times in Nigeria as a result of socio-economic development including wage increases. In Nigeria, much has been, and is being, invested on municipal solid waste management in cities. But, little progress has been made because of severe financial, technological and institutional constraints within the Public and the private sectors apart from erratic growth of housing units in the inner core of urban cities (Ojeshina, 1999; Omishakin and Sridhar, 1985). Despite the best attempts at waste avoidance, reduction, reuse and recovery (recycling, composting and energy recovery), landfill and open dump waste disposal sites are still the principal focus for ultimate disposal of residual wastes and incineration residues world-wide (Charlotte, 1998; Waite, 1995).

Open dumps have been demonstrated by several scholars to pose serious threat to groundwater and surface water resources (Fatta et al., 1999), especially those constructed and operated without impermeable liners to reduce the potential of contamination. The degree of threat is strongly influenced by the composition of the wastes in the dump site and the volume of leachates from the waste mass generated, as well as the location of the dump sites from water bodies; groundwater and surface water (Slomwczynska and Slomcyznski, 2004).

The decomposition of wastes in dump site is enhanced by moisture from precipitation, and physical, chemical and biological processes. Present in the dump site are liquid and gaseous phases. The gaseous phase consists of carbon dioxide $\left(\mathrm{CO}_{2}\right)$ and methane $\left(\mathrm{CH}_{4}\right)$, while the liquid phase is very complex chemically and its composition is characterized by the presence of different types of dissolved organic compounds, inorganic compounds and heavy metals. This liquid which is generated as a result of runoff from dump sites is known as leachate. This accumulates at the bottom of dump sites and subsequently percolates slowly into the soil to contaminate aquifer beneath it and adjacent surface water bodies. Leachate is a widely used term in environmental sciences where it has the specific meaning of a liquid that has dissolved or entrained environmentally harmful substances which may then enter the environment and pollute the surrounding water sources and contamination of soil (Khan, 2001). Leachate from a dump site varies widely in composition depending on the age of the dump site and type of waste that it contains. Dump site leachate may be characterized as a water based solution of four groups of contaminants; dissolved organic matter (alcohols, acids, aldehydes, short chain sugar etc.), inorganic macro components (common cations and anions including sulphate, chloride, iron, aluminium, zinc and ammonia), heavy metals ( $\mathrm{Pb}, \mathrm{Ni}, \mathrm{Cd}, \mathrm{Hg})$, and xenobiotic organic compounds such as halogenated organics (PCBs, dioxins etc.) (Christensen et al., 2001; Torabian et al., 2004; Pivato and Gaspari, 2005). The physical appearance of leachates when it emerges from typical dump site is a strongly coloured black, yellow or orange cloudy liquid. The smell is offensive and may be very pervasive because of hydrogen, nitrogen and sulphur rich organic species such as mercaptans (Singh et al., 2007).

In the course of waste stabilization, the organic constituents of leachates tend to decompose and stabilize with time and the inorganic constituents remain even long after stabilization has taken place (Jhamnani and Singh, 2009; Longe and Balogun, 2010). According to Slomwczynska and Slomcyznski (2004), the very old dump sites produces leachates that is alkaline in nature, whose $\mathrm{pH}$ ranges from 7.0 to 7.9 , while dump sites whose leachates' $\mathrm{pH}$ ranges from 3.5 to 6.5 
indicate leachates that are generated in the initial period of decomposition of waste.

This study was aimed at characterizing the leachate quality of selected dump sites in Port Harcourt metropolis, with the view of knowing its content and likely environmental consequences.

\section{MATERIALS AND METHODS}

\section{Description of study area}

Port Harcourt City, founded in 1913 has an estimated population of about 7.0 million people. It lies between longitude $6^{0} 4^{\prime} \mathrm{S}-7^{0} 1^{\prime} \mathrm{E}$ and latitude $4^{0} 40^{\prime}-5^{0} 00^{\prime} \mathrm{N}$. It covers an estimated area of 1811.6 square kilometer. The City is situated at an average height of $150 \mathrm{~m}$ drained by 4 river basins and surrounded by secondary rainforest as well as savannahs. It experiences a mainly tropical climate with an estimated annual rainfall of about $1200 \mathrm{~mm}$ and mean annual temperature of $29^{\circ} \mathrm{C}$ (Braide et al., 2004).

\section{Sampling locations}

The sample locations were Nkpolu Junction along East-West Road (LS1), Chindah Borrow Pit, off Chindah Road, Mile 4(LS2) and Rumuepirikom Community, off Iwofe Road (LS3). These dump sites receive a mixture of municipal, commercial, and mixed industrial wastes with hazardous and nonhazardous constituents (Figure 1).

\section{Nkpolu location (LS1)}

Nkpolu location is an abandoned dump site site that is located by Rumuigbo Junction, along East West Road, approximately $10 \mathrm{~km}$ East from University of Port Harcourt main gate. The dump site as shown in plate $1 \mathrm{a}$, is delineated on Latitude $4^{0} 52^{\prime} 08.9^{\prime} \mathrm{N}$ and Longitude $6^{0} 58^{\prime} 52.8^{\prime} \mathrm{E}$. While in existence, the dump site received waste from domestic, market, commercial, industrial and academic institutional origins.

\section{Chindah Borrow-Pit location (LS2)}

Chindah borrow-Pit location is an active dump site located off Chindah Road, Rumueme Community, Port Harcourt. It is surrounded by commercial, industrial and residential set up and delineated on Latitude $4^{0} 49^{\prime} 18.5^{\prime} \mathrm{N}$ and Longitude 6 ${ }^{0} 58^{\prime} 18.9^{\prime} \mathrm{E}$. The wastes are of different types, ranging from organic to inorganic, hazardous and non hazardous. Like in all other existing dump sites in the state, the waste stream is made up of domestic, commercial, industrial and institutional (religious and academic) origins (Longe and Balogun, 2010). The Chindah borrow pit dump site shown in plate $1 \mathrm{c}$ is a non-engineered landfill with a huge heap of waste. Trucks from different parts of Port Harcourt collect and bring wastes to this site and dump them in irregular fashion. The wastes are dumped without separation but the rag pickers who constitute the informal sector rummage through the waste, help in segregating them by collecting the plastic and metals and sell same to the recycling industries.

\section{Rumuepirikom location (LS3)}

Rumuepirikom location is an abandoned dump site that is located off Iwofe Road. The landfill is delineated between Latitude $4^{0} 49^{\prime} 40.3^{\prime \prime} \mathrm{N}$ and Longitude $6^{0} 57$ '55.6"E. While in operation, the dump site as shown in plate $1 \mathrm{c}$, received a mixture of municipal, commercial, and mixed industrial wastes with hazardous and nonhazardous constituents. 


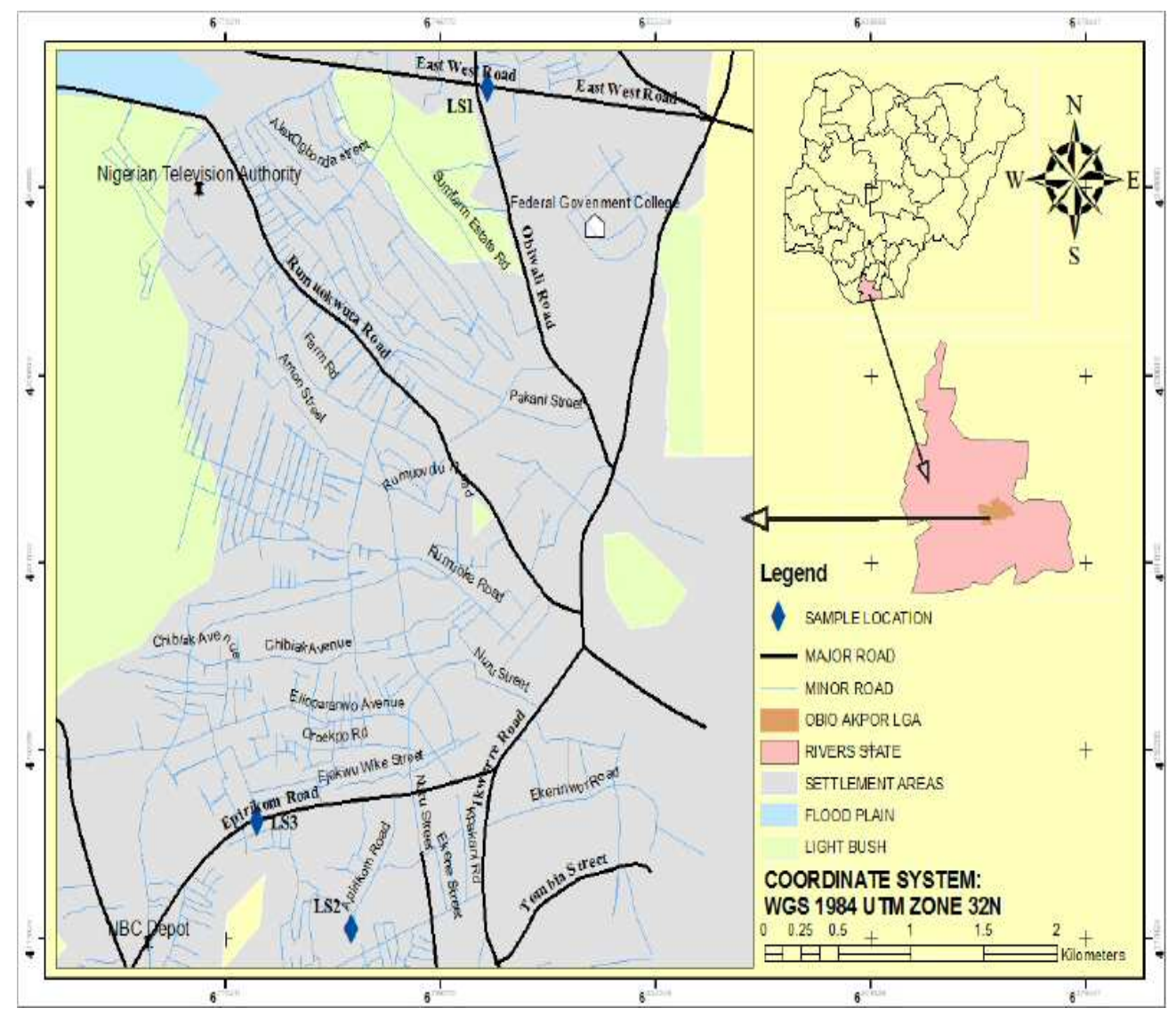

Figure 1: GIS Based Map of the study area.

\section{Leachate sampling and analyses}

Since the dump site was not equipped with a leachate collector, leachate drains were strategically constructed by the research team, to collect effluents from the waste mass into a pond by gravity and leachates were collected during a rainy period. To determine the quality of the leachates, samples were collected from the randomly selected leachate drains at the site (APHA, 2005). Leachate samples were collected using 1-litre plastic bottles that had been cleaned by soaking in $10 \%$ nitric acid and rinsed with distilled water, at the sampling site, the bottles were rinsed thrice with the leachate to be sampled prior to filling and it was labeled LS1, LS2 and LS3 for Nkpolu, Chindah borrow pit and Rumueprikom sites respectively. In-situ measurements were taken and the samples were quickly transferred to the laboratory, were they were filtered through glass microfiber filter $(0.47 \mathrm{~mm})$ and stored at $4{ }^{\circ} \mathrm{C}$. Thereafter, sample analysis was carried out in the laboratory.

Analytical methods were according to "Standard methods for examination of water and wastewater" unless otherwise stated (APHA, 2005). $\mathrm{pH}$ was determined by glass electrode method with a standard calibrated pH. Dissolved solids, and conductivity were metered in situ. An Atomic Absorption Spectrophotometer (contra ${ }^{\circledR} 300$ model) was used for metals analyses after samples were digested, using concentrated trioxonitrate $(\mathrm{V})$ acid and the volume made up to $50 \mathrm{~mL}$ with deionized water. Dissolved oxygen (DO) was determined by Azide modification of Winkler's method. Open reflux method utilising potassium tetra-oxo chromate (VI) in boiling concentrated tetra-oxosulphate (VI) solution in the presence of silver catalyst was used to determine COD. Phosphate was 
analysed by colorimetry using molybdovanadate method, while chloride was determined by Mohr's Argentometric method and sulphate was analysed using turbidimetric method by APHA.

\section{RESULTS}

The results obtained from the leachates characterization of dump sites located at Nkpolu Junction along East-West Road, Chindah Borrow-Pit off Chindah Road, Mile 4 and Rumuepirikom Community (off Iwofe Road), are as presented in Tables $2-4$. The mean concentrations of the parameters measured in the locations as compared with Federal Ministry of Environment (FMenv) Standard on waste water are presented in Table 5 and Figures $2-3$. Table 6 shows the relationship between $\mathrm{BOD}_{5}$ and $\mathrm{COD}$, which is a measure of the age and organic strength of the dumpsites.

Table 1: Sampling pointsand geographical coordinates.

\begin{tabular}{|c|c|}
\hline Sample Location & Coordinates \\
\hline \multirow[t]{2}{*}{ LS1 } & $\mathrm{N}: 4^{0} 52^{\prime} 08.9^{\prime \prime} \mathrm{N}$ \\
\hline & E: $6^{0} 58^{\prime} 52.8^{\prime \prime} \mathrm{E}$ \\
\hline \multirow[t]{2}{*}{ LS2 } & $\mathrm{N}: 4^{0} 49^{\prime} 18.5^{\prime \prime} \mathrm{N}$ \\
\hline & E: $6^{0} 58^{\prime} 18.9^{\prime \prime} \mathrm{E}$ \\
\hline \multirow[t]{2}{*}{ LS3 } & $\mathrm{N}: 4^{0} 49^{\prime} 40.3^{\prime \prime} \mathrm{N}$ \\
\hline & E: $6^{0} 57^{\prime} 55.6^{\prime \prime} \mathrm{E}$ \\
\hline
\end{tabular}

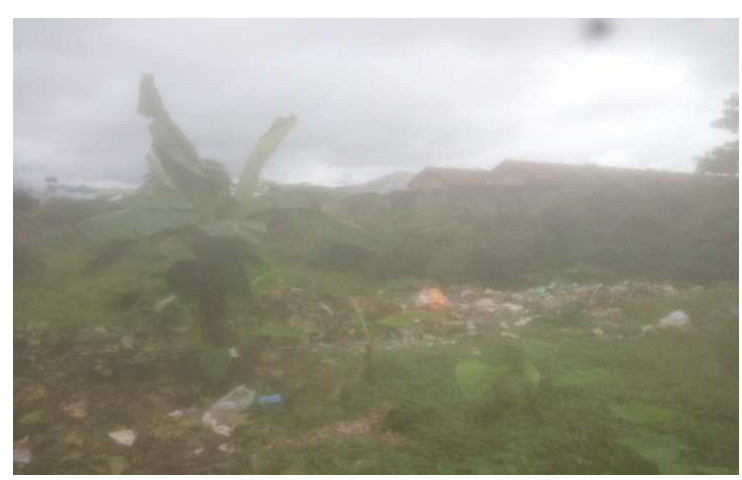

$1 \mathbf{a}$

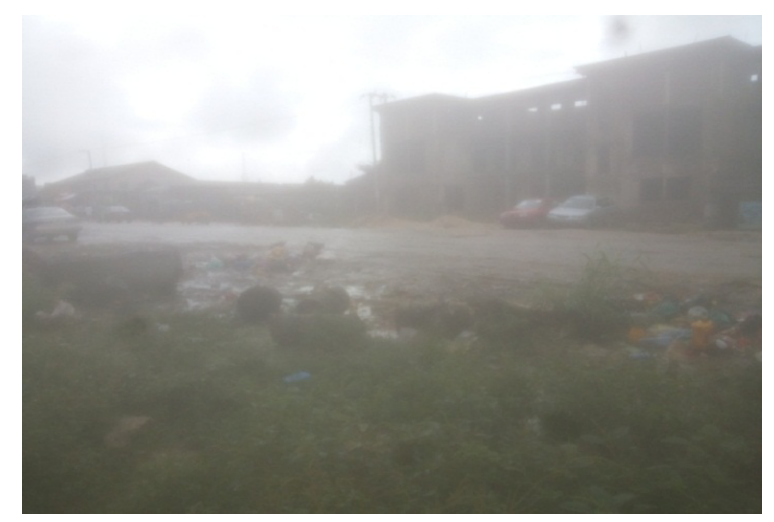

$1 \mathbf{b}$ 


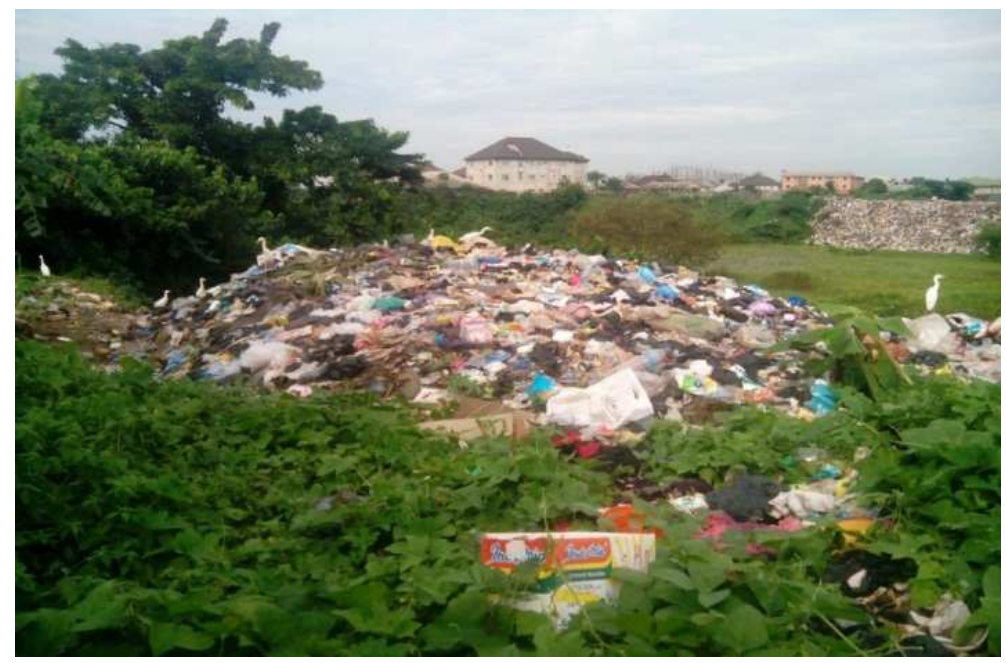

$1 c$

Plates 1a, b \& c: Nkpolu abandoned dump site off East-West Road, Rumuepirikom. Abandoned dump site off Iwofe Road and Chindah Borrow-pit off Chindah Road, Port Harcourt.

Table 2: Leachate characterization of samples from LS1.

\begin{tabular}{|c|c|c|c|c|c|}
\hline \multirow[t]{2}{*}{$\mathbf{S} / \mathbf{N}$} & \multirow[t]{2}{*}{ Parameters } & \multicolumn{4}{|c|}{ Leachate sample location 1 (LS1) } \\
\hline & & $1^{\text {st }}$ & $2^{\text {nd }}$ & $3^{\text {rd }}$ & Mean \\
\hline 1. & $\mathrm{pH}$ & 7.94 & 8.15 & 7.79 & 7.96 \\
\hline 2. & Total Dissolved Solid (mg/l) & 70.0 & 72.3 & 69.8 & 70.7 \\
\hline 3. & Electrical Conductivity $(\mu \mathrm{S} / \mathrm{cm})$ & 150 & 174 & 80 & 134.7 \\
\hline 4. & Phosphate $(\mathrm{mg} / \mathrm{l})$ & 1.044 & 1.028 & 1.015 & 1.029 \\
\hline 5. & Sulphate (mg/l) & 1.875 & 2.250 & 1.860 & 1.995 \\
\hline 6. & Chlorides $(\mathrm{mg} / \mathrm{l})$ & 33.9 & 35.7 & 31.2 & 33.6 \\
\hline 7. & Biological Oxygen Demand (mg/l) & 2.0 & 2.5 & 2.4 & 2.3 \\
\hline 8. & Chemical Oxygen Demand (mg/l) & 3.09 & 3.15 & 3.06 & 3.10 \\
\hline 9. & Dissolved Oxygen (mg/l) & 1.35 & 1.39 & 0.98 & 1.24 \\
\hline 10. & $\operatorname{Lead}(\mathrm{mg} / \mathrm{l})$ & 0.006 & 0.008 & 0.004 & 0.006 \\
\hline 11. & Zinc (mg/l) & 0.105 & 0.113 & 0.076 & 0.098 \\
\hline 12. & Iron $(\mathrm{mg} / \mathrm{l})$ & 0.179 & 0.184 & 0.165 & 0.176 \\
\hline 13. & Chromium (mg/l) & 0.001 & 0.001 & 0.001 & 0.001 \\
\hline 14. & Copper (mg/l) & 0.114 & 0.116 & 0.112 & 0.114 \\
\hline 15. & Nickel (mg/l) & 0.001 & 0.001 & 0.001 & 0.001 \\
\hline 16. & Cadmium (mg/l) & 0.001 & 0.001 & 0.001 & 0.001 \\
\hline
\end{tabular}


Table 3: Leachate characterizations of samples from LS2.

\begin{tabular}{|c|c|c|c|c|c|}
\hline \multirow[t]{2}{*}{$\mathbf{S} / \mathbf{N}$} & \multirow[t]{2}{*}{ Parameters } & \multicolumn{4}{|c|}{ Leachate sample location 2 (LS2) } \\
\hline & & $\mathbf{1}^{\text {st }}$ & 2nd & 3rd & Mean \\
\hline 1. & $\mathrm{pH}$ & 6.57 & 6.62 & 6.46 & 6.55 \\
\hline 2. & Total Dissolved Solid (mg/l) & 5333 & 5525 & 4099 & 4985 \\
\hline 3. & Electrical Conductivity $(\mu \mathrm{S} / \mathrm{cm})$ & 9646 & 9975 & 7970 & 9197 \\
\hline 4. & Phosphate $(\mathrm{mg} / \mathrm{l})$ & 13.76 & 14.09 & 11.13 & 12.99 \\
\hline 5. & Sulphate (mg/l) & 6.975 & 7.060 & 6.785 & 6.940 \\
\hline 6. & Chlorides (mg/l) & 2432 & 2226 & 2126 & 2261 \\
\hline 7. & Biological Oxygen Demand (mg/l) & 5.97 & 6.06 & 5.82 & 5.95 \\
\hline 8. & Chemical Oxygen Demand (mg/l) & 14.23 & 16.41 & 13.97 & 14.87 \\
\hline 9. & Dissolved Oxygen (mg/l) & 0.82 & 0.96 & 0.79 & 0.85 \\
\hline 10. & Lead $(\mathrm{mg} / \mathrm{l})$ & 0.012 & 0.014 & 0.010 & 0.012 \\
\hline 11. & Zinc (mg/l) & 0.152 & 0.162 & 0.148 & 0.154 \\
\hline 12. & Iron $(\mathrm{mg} / \mathrm{l})$ & 0.452 & 0.501 & 0.501 & 0.461 \\
\hline 13. & Chromium (mg/l) & 0.002 & 0.003 & 0.004 & 0.003 \\
\hline 14. & Copper (mg/l) & 0.177 & 0.181 & 0.173 & 0.177 \\
\hline 15. & Nickel (mg/l) & 0.004 & 0.005 & 0.003 & 0.004 \\
\hline 16. & Cadmium (mg/l) & 0.008 & 0.010 & 0.006 & 0.008 \\
\hline
\end{tabular}

Table 4: Leachate characterization of samples from LS3.

\begin{tabular}{|c|c|c|c|c|c|}
\hline \multirow[t]{2}{*}{$\mathbf{S} / \mathbf{N}$} & \multirow[t]{2}{*}{ Parameters } & \multicolumn{4}{|c|}{ Leachate sample location 3 (LS3) } \\
\hline & & $1^{\text {st }}$ & 2nd & 3rd & Mean \\
\hline 1. & $\mathrm{pH}$ & 7.42 & 7.49 & 7.37 & 7.43 \\
\hline 2. & Total Dissolved Solid (mg/l) & 1112 & 1140 & 939.4 & 1064 \\
\hline 3. & Electrical Conductivity $(\mu \mathrm{S} / \mathrm{cm})$ & 1946 & 2162 & 1814 & 1974 \\
\hline 4. & Phosphate $(\mathrm{mg} / \mathrm{l})$ & 5.375 & 5.512 & 5.151 & 5.346 \\
\hline 5. & Sulphate (mg/l) & 3.025 & 3.652 & 2.953 & 3.210 \\
\hline 6. & Chlorides (mg/l) & 606.2 & 613.3 & 575.4 & 598.3 \\
\hline 7. & Biological Oxygen Demand (mg/l) & 2.85 & 3.19 & 2.78 & 2.94 \\
\hline 8. & Chemical Oxygen Demand (mg/l) & 7.29 & 7.71 & 7.05 & 7.35 \\
\hline 9. & Dissolved Oxygen (mg/l) & 0.55 & 0.59 & 0.54 & 0.56 \\
\hline 10. & Lead $(\mathrm{mg} / \mathrm{l})$ & 0.008 & 0.009 & 0.007 & 0.008 \\
\hline 11. & Zinc (mg/l) & 0.143 & 0.144 & 0.130 & 0.139 \\
\hline 12. & Iron $(\mathrm{mg} / \mathrm{l})$ & 0.253 & 0.302 & 0.204 & 0.253 \\
\hline 13. & Chromium (mg/l) & 0.002 & 0.003 & 0.001 & 0.002 \\
\hline 14. & Copper $(\mathrm{mg} / \mathrm{l})$ & 0.139 & 0.148 & 0.130 & 0.139 \\
\hline 15. & Nickel (mg/l) & 0.001 & 0.001 & 0.001 & 0.001 \\
\hline 16. & Cadmium (mg/l) & 0.004 & 0.005 & 0.003 & 0.004 \\
\hline
\end{tabular}


Table 5: Comparison of mean leachate characterization for all sampling locations with FMENV standard.

\begin{tabular}{|c|c|c|c|c|c|}
\hline $\mathbf{S} / \mathbf{N}$ & Parameters & $\begin{array}{l}\text { Location } 1 \\
\quad \text { (LS1) }\end{array}$ & $\begin{array}{l}\text { Location } 2 \\
\text { (LS2) }\end{array}$ & $\begin{array}{l}\text { Location } 3 \\
\text { (LS3) }\end{array}$ & $\begin{array}{l}\text { FMENV } \\
\text { Standard }\end{array}$ \\
\hline 1. & $\mathrm{pH}$ & 7.96 & 6.55 & 7.43 & 5.0 \\
\hline 2. & Total Dissolved Solid (mg/l) & 70.7 & 4985 & 1064 & 500 \\
\hline 3. & $\begin{array}{c}\text { Electrical Conductivity } \\
(\mu \mathrm{S} / \mathrm{cm})\end{array}$ & 134.7 & 9197 & 1974 & 125.00 \\
\hline 4. & Phosphate (mg/l) & 1.029 & 12.997 & 5.346 & 50.00 \\
\hline 5. & Sulphate (mg/l) & 1.995 & 6.940 & 3.210 & 100.00 \\
\hline 6. & Chlorides $(\mathrm{mg} / \mathrm{l})$ & 33.6 & 2261 & 598.3 & 100.00 \\
\hline 7. & $\begin{array}{l}\text { Biological Oxygen Demand } \\
\qquad(\mathrm{mg} / \mathrm{l})\end{array}$ & 1.24 & 5.95 & 2.94 & 30.00 \\
\hline 8. & $\begin{array}{l}\text { Chemical Oxygen Demand } \\
\qquad(\mathrm{mg} / \mathrm{l})\end{array}$ & 3.10 & 14.87 & 7.35 & 75.00 \\
\hline 9. & Dissolved Oxygen (mg/l) & 2.3 & 0.85 & 0.56 & 5.00 \\
\hline 10. & Lead $(\mathrm{mg} / \mathrm{l})$ & 0.006 & 0.012 & 0.008 & 0.05 \\
\hline 11. & Zinc (mg/l) & 0.098 & 0.154 & 0.139 & $6.00-9.00$ \\
\hline 12. & Iron $(\mathrm{mg} / \mathrm{l})$ & 0.176 & 0.461 & 0.253 & 0.05 \\
\hline 13. & Chromium (mg/l) & 0.001 & 0.003 & 0.002 & 0.20 \\
\hline 14. & Copper (mg/l) & 0.114 & 0.177 & 0.139 & 5.00 \\
\hline 15. & Nickel (mg/l) & 0.001 & 0.004 & 0.001 & 0.01 \\
\hline 16. & Cadmium (mg/l) & 0.001 & 0.008 & 0.004 & 0.01 \\
\hline
\end{tabular}

Table 6: $\mathrm{BOD}_{5}$ to COD ratio (Organic strength of the dump sites).

\begin{tabular}{lccccc}
\hline S/N & Parameters & Location 1 & Location 2 & Location 3 & $\begin{array}{c}\text { FMenv } \\
\text { Standard }\end{array}$ \\
\hline 1 & $\begin{array}{c}\text { Biological Oxygen } \\
\text { Demand (BOD) (mg/l) } \\
\text { Chemical Oxygen }\end{array}$ & 1.24 & 5.95 & 2.94 & 30.00 \\
2 & 3.10 & 14.87 & 7.35 & 75.00 \\
3 & $\begin{array}{c}\text { Demand (COD) (mg/l) } \\
\text { BOD } / \text { /COD }\end{array}$ & 0.4 & 0.4 & 0.4 & 0.4 \\
\hline
\end{tabular}




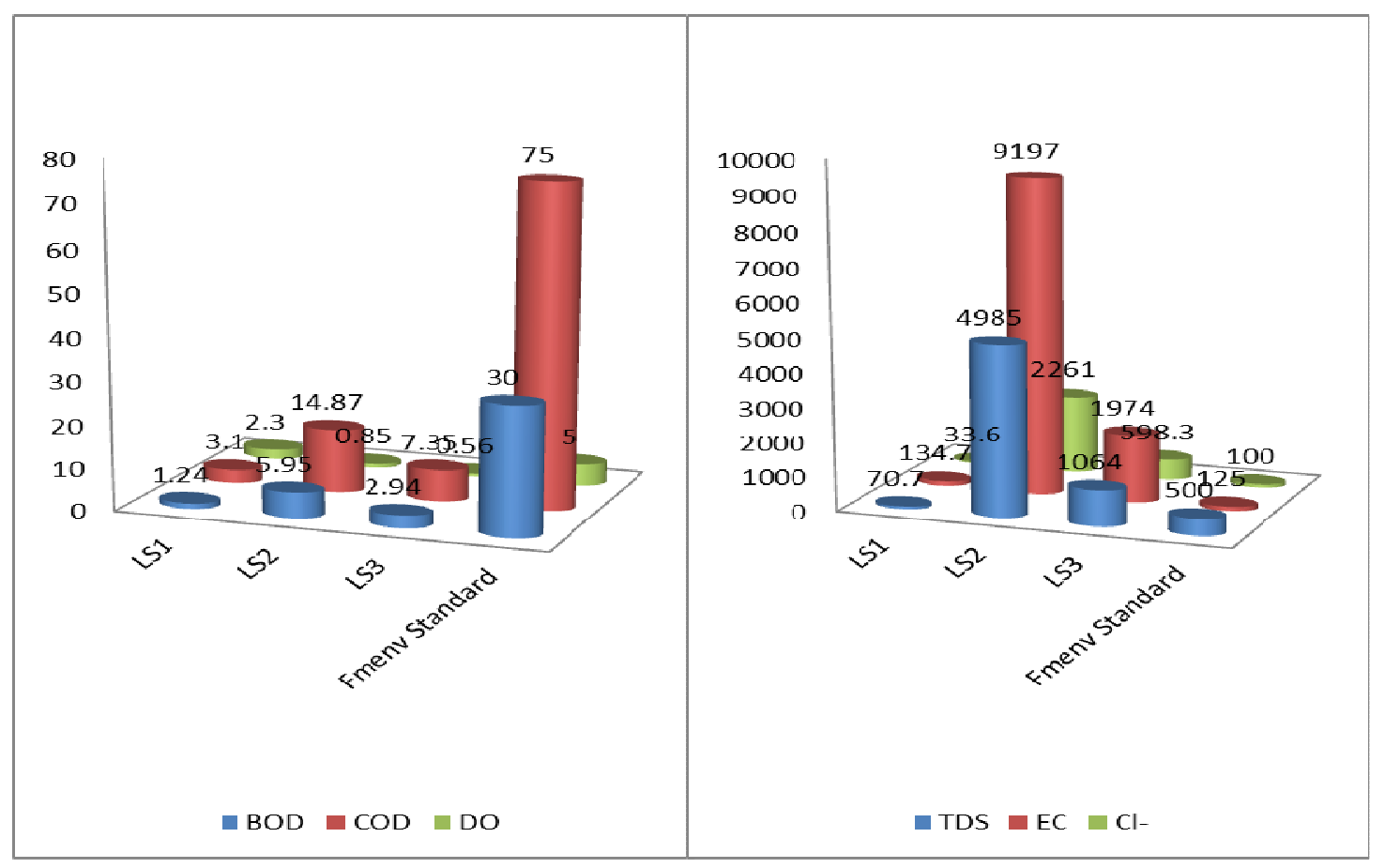

Heavy Metal Concentration in Sample Locations

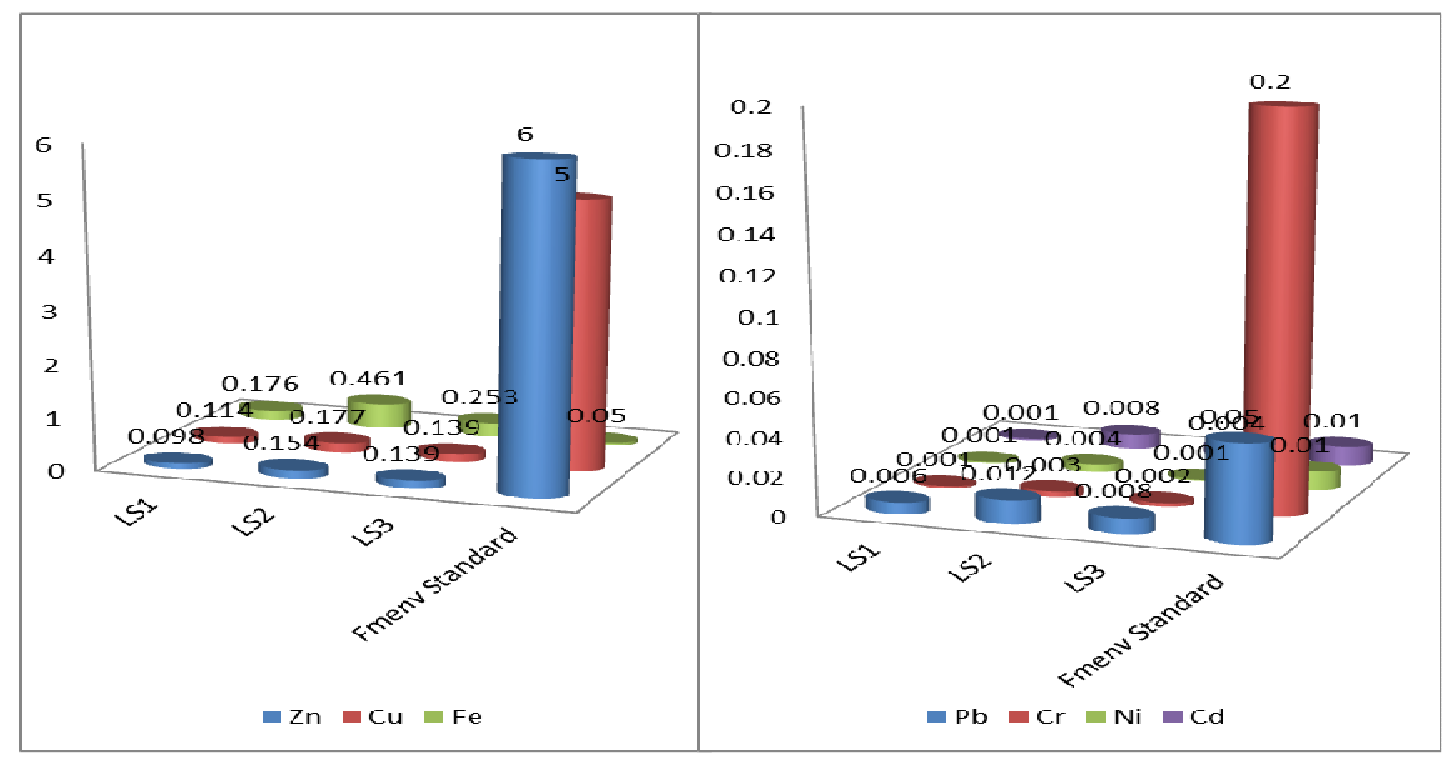

Figure 3: Heavy metal content in sample locations. 


\section{DISCUSSION}

The $\mathrm{pH}$ values for the leachate samples examined for LS1 ranged from 7.79-8.15 with a mean value of 7.96, that of LS2 ranged from $6.46-6.62$ with a mean value of 6.55 and $\mathrm{pH}$ values for LS3 ranged from 7.37 - 7.49, with mean value of 7.43 . The different mean $\mathrm{pH}$ values showed the various stages of the decomposition of waste and age of the dump site in the study locations. The high $\mathrm{pH}$ value of LS1 and LS3 showed that the dump sites were close to maturation stage (old dump site) and were no longer active, while the low $\mathrm{pH}$ value of LS2 is a strong reflection of an acid producing phase during the decomposition of wastes, the low value of $\mathrm{pH}$ measured, according to Alloway (1995) is an indication of leachate undergoing anaerobic or methanogenic phase. Slomczynka and Slomcyznski (2004) noted that the very old landfill produces leachates that are alkaline in nature, whose $\mathrm{pH}$ ranges from 8.0 to 8.5. However, those landfill whose leachates $\mathrm{pH}$ ranges from 3.5 to 6.5 indicate leachates that are generated in the initial period of decomposition of waste. The acidic nature also indicates the presence of carboxylic acids or carbonate ions in the leachate.

Similarly, Fatta et al. (1999) observed that the initial period of leachate formation is characterized by very low $\mathrm{pH}$ values and later with higher $\mathrm{pH}$ values at the methanogenic phase. The leachate from LS2 with a mean $\mathrm{pH}$ of 6.55 is therefore more acidic than the mean $\mathrm{pH}$ values of LS3 (7.43) and LS1 (7.96) respectively. The mean electrical conductivity (EC) values for the three leachate sample locations depict different values, in which LS2 has the highest value of $9197 \mu \mathrm{S} / \mathrm{cm}$, followed by LS3 with value of $1974 \mu \mathrm{S} / \mathrm{cm}$, while the lowest value of $134.7 \mu \mathrm{S} / \mathrm{cm}$ was recorded for the LS1 leachate sample. These values reflect the presence of anions or inorganic materials in the leachate samples. There is significant variation in the mean values of total dissolved solids (TDS) among the three leachate sample locations, of which LS2 has the highest value of $4985 \mathrm{mg} / \mathrm{l}, \mathrm{LS} 3$ with a value of $1063 \mathrm{mg} / \mathrm{l}$ and LS1 with value of $70.7 \mathrm{mg} / 1$. Locations 2 and 3 had values that fell way above the regulatory limit.

The value of $\mathrm{BOD}_{5}$ in leachate tends to indicate the maturity of the landfill/dump site. The values are relatively different for all leachate sample locations. Comparing the three, LS2 has a maximum value of $5.95 \mathrm{mg} / \mathrm{l}$, LS2 with a value of $2.94 \mathrm{mg} / \mathrm{l}$ and LS1 with the minimum value of $1.24 \mathrm{mg} / \mathrm{l}$. Similarly, the COD values are in the same trend but with higher values, with LS2 having a $14.87 \mathrm{mg} / \mathrm{l}$, LS3 with a value of $7.35 \mathrm{mg} / \mathrm{l}$ and LS1 with a value of $3.10 \mathrm{mg} / \mathrm{l}$. These values obtained for both $\mathrm{BOD}_{5}$ and $\mathrm{COD}$ are consistent with previous works of Ehrig (1989) and Christensen et al. (2001) for a typical municipal landfill leachate. The high values of $\mathrm{BOD}_{5}$ observed for LS2 is explained by microbial activity in the decomposing leachate yet to attained stability. The calculated ratio of 0.4 for $\mathrm{BOD}_{5} / \mathrm{COD}$ (Table 6) suggests high organic strength for the dump sites and this ratio is similar to those obtained by previous researchers (Yoshida et al., 2002; Amina, 2004; Bahaa, 2005). The ratio of $\mathrm{BOD}_{5} / \mathrm{COD}$ also indicates the oldness of the landfill, as portrayed by Curi et al. (1994). They reported that ratios of $\mathrm{BOD}_{5} / \mathrm{COD}$ which vary from 0.4 $\mathrm{mg} / \mathrm{l}$ to $0.6 \mathrm{mg} / \mathrm{l}$ are characteristics of a young landfill and this ratio decreases to $0.05 \mathrm{mg} / \mathrm{l}$ to $0.2 \mathrm{mg} / \mathrm{l}$ for a matured landfill. In addition, Irene (1996) asserted that as the $\mathrm{BOD}_{5} / \mathrm{COD}$ ratio decreases, the age of the landfill increases. The above assertion is applicable to LS1 and LS3 dump sites that have been closed and no longer receive wastes. Anions analyzed include chlorides $\left(\mathrm{Cl}^{-}\right)$, sulphates $\left(\mathrm{SO}_{4}{ }^{2-}\right)$ and phosphates $\left(\mathrm{PO}_{4}{ }^{3-}\right)$. The mean value of $\mathrm{Cl}^{-}$ranged between $33.6 \mathrm{mg} / \mathrm{l}$ and $2261 \mathrm{mg} / 1, \mathrm{LS} 2$ has the highest value and LS1 has the lowest value. Chloride is similar to nitrate in being a conservative contaminant and therefore poses serious threat to groundwater pollution. According to Fatta et al. (1999) chlorides as well as nitrates are conservative contaminants as they are not affected by biochemical processes and natural decontamination processes taking place inside the landfill as well as their infiltration into the 
vadosezone. This explains why chlorides are potential threat to ground water pollution. The mean sulphate values for the three sample locations of leachate examined are quite variable and may have emanated from oxidation of iron sulphide present at LS2 dump site. The maximum value obtained is $6.940 \mathrm{mg} / \mathrm{l}$ for LS2 and the minimum value is $1.995 \mathrm{mg} / \mathrm{l}$. The concentration of phosphate was higher in LS2 with a value of 12.997 $\mathrm{mg} / \mathrm{l}$, followed by LS3 with a value of 5.346 $\mathrm{mg} / \mathrm{l}$ and LS1 the least, with a value of 1.029 $\mathrm{mg} / \mathrm{l}$. The presence of $\mathrm{PO}_{4}{ }^{3-}$ in a leachate is dangerous as its presence in water increases eutrophication and correspondingly promotes the growth of algae.

The heavy metals content of the leachate samples as shown in Table 5, obtained from the laboratory analysis include Lead $(\mathrm{Pb})$, Zinc $(\mathrm{Zn})$, Iron $(\mathrm{Fe})$, Chromium $(\mathrm{Cr})$, Copper $(\mathrm{Cu})$, Nickel $(\mathrm{Ni})$ and Cadmium (Cd). Similar results have also been detected in leachate samples by Christensen et al. (1994). In LS1, Iron (Fe) had the highest mean concentration of $0.176 \mathrm{mg} / \mathrm{l}$ of all the heavy metals present in the leachate sample, followed by copper with value of $0.114 \mathrm{mg} / \mathrm{l}$, whereas the lowest metals with mean concentration of $0.001 \mathrm{mg} / \mathrm{l}$ were obtained in $\mathrm{Cr}$, Ni and Cd. In LS2, Iron (Fe) also had the highest mean concentration of $0.461 \mathrm{mg} / \mathrm{l}$ of all the heavy metals present in the leachate sample, followed by copper with value of $0.177 \mathrm{mg} / \mathrm{l}$, whereas the lowest where $\mathrm{Ni}$ with $0.004 \mathrm{mg} / \mathrm{l}$ and $\mathrm{Cr}$ with $0.003 \mathrm{mg} / \mathrm{l}$. In LS3, Iron $(\mathrm{Fe})$ still had the highest mean concentration of $0.253 \mathrm{mg} / \mathrm{l}$ of all the heavy metals present in the leachate sample, followed by copper and Zinc with same mean values of $0.139 \mathrm{mg} / \mathrm{l}$, lead was $0.008 \mathrm{mg} / \mathrm{l}$ while the lowest was Nickel with $0.001 \mathrm{mg} / \mathrm{l}$. The maximum mean concentration values of all the heavy metals examined is highest in LS2. The high level of (Fe), in the leachate samples is evidence of dumping of iron and steel scraps wastes in the dump site. The quantity of $\mathrm{Pb}$, though small, is attributed to availability of $\mathrm{Pb}$ related wastes such as batteries, paints and photography processing chemicals in the dump site (Moturi et al., 2004; Mor et al., 2005). The concentration of $\mathrm{Zn}$ depicts the dumping of batteries and fluorescent lamps in the dump site. Also detected in the leachate samples are $\mathrm{Cr}$ and $\mathrm{Cu}$. The presence of $\mathrm{Cr}$ in the leachate samples may have originated from the emission of automobile exhaust of diesel tanker vehicles which use the vicinity of the dump site as a garage, while collecting metal scraps from the dump site. Copper $(\mathrm{Cu})$ is thought to have originated from the dumping of waste related to cement like bags in the dumpsite (Masood and Malik, 2011). The different heavy metals detected is indication that the dump site in Port Harcourt Metropolis receives variety of wastes that reflects the origin of $\mathrm{Pb}, \mathrm{Zn}, \mathrm{Fe}, \mathrm{Cu}, \mathrm{Cr}, \mathrm{Ni}$ and $\mathrm{Cd}$ (Moturi et al., 2004; Mor et al., 2005).The low value of heavy metals obtained maybe attributed to the dumping of mainly municipal wastes and small percentage of industrial wastes.

\section{Comparative study of mean leachate values with FMENV standard \\ The overall mean leachate} characteristics in all sample locations are presented alongside with the Nigerian FMENV standard in Table 5. The leachate samples from the study areas were slightly acidic (LS2) with a $\mathrm{pH}$ value of 6.55 and slightly alkaline (LS3 and LS1) with a $\mathrm{pH}$ value of 7.43 and 7.96 respectively. The variation of $\mathrm{pH}$ concentrations shows the different stages of decomposition of waste matter in the dump sites. The conductivity values were generally above the specified standard value of $125 \mu \mathrm{S} / \mathrm{cm}$. The mean concentration of total dissolved solids in LS2 and LS3 were found to exceed the recommended limit of $500 \mathrm{mg} / \mathrm{l}$. LS2 recorded a mean value of $4985 \mathrm{mg} / \mathrm{l}$ while that of LS3 was $1064 \mathrm{mg} / \mathrm{l}$.

The anions present in the leachates fell within the recommended standard, with the exception of chlorides. Chlorides concentration in LS2 and LS3 were higher than $100 \mathrm{mg} / \mathrm{l}$ stipulated by FMENV. LS2 had 
a mean value of $2261 \mathrm{mg} / \mathrm{l}$ while LS3 recorded a value of $598.3 \mathrm{mg} / \mathrm{l}$. The BOD and COD values observed in the study areas were generally below the recommended standard. The BOD/COD ratio for all sample locations had a value of 0.4 indicating stabilized leachates. Likewise the DO values were low compared with those known with strong leachates. These lower range constituents are other pointers to the fact that the leachates of the dump sites considered in the study area were in their methanogenic stage and were therefore relatively stabilized.

All heavy metals present in the leachates from the dump site fell within FMENV standard, with exception of Iron. Iron was the only metal that exceeded the recommend limit of $0.05 \mathrm{mg} / \mathrm{l}$. LS1 had a concentration of $0.176 \mathrm{mg} / \mathrm{l}, \mathrm{LS} 2$ was 0.461 $\mathrm{mg} / \mathrm{l}$ and that of LS3 was $0.253 \mathrm{mg} / \mathrm{l}$. These values indicate iron pollution which could be as a result of discarding of metal scraps in the dump sites.

Other parameters recorded in the study area are phosphate, sulphate, lead, zinc, chromium, copper, nickel and cadmium. As indicated in Table 5, these parameters mean values were either below or within the FMENV regulations. And as such, it could be adjudged that the leachate do not pose any environment threat or pollution in the study area.

\section{Conclusion}

The low $\mathrm{pH}$ value and high concentration of pollutants obtained for Chindah Borrow-Pit indicated that the wastes in the dump site were still decomposing and were in the anaerobic or methanogenic phase, hence the leachates has the capacity to contaminate the ground water in the surrounding aquifer. The high $\mathrm{pH}$ values for Nkpolu Junction and Rumuepirikom Community dump sites as well as the low concentrations of the pollutants indicated that the dump sites were near maturation stage due to the depletion of readily-degradable organic matter and therefore pose no imminent threat to ground water. This study recommends that
Chindah Borrow-Pit (LS2) dump site be given immediate attention in order to avoid pollution to ground water and threat to human health and should be upgraded to a wellengineered sanitary landfill.

\section{REFERENCES}

Alloway BJ. 1995. Heavy Metals in Soils $\left(2^{\text {nd }}\right.$ edn). Chapman and Hall: London, UK.

Amina C, Abdekader Y, Elkbri L, Jacky M, Alain V. 2004. Environmental Impact of an Urban Landfill on a Costal Aquifer (El Jadida, Morocco). Journal of African Earth Sciences, 39: 509-516.

APHA. 2005. Standard Methods for the Examination of Water and Waste Water $\left(21^{\text {st }}\right.$ edn). American Public Health Association: Washington DC.

Bahaa EW. 2005. The Migration of Inorganic Contaminants from Landfill Sites into the Soil and Groundwater System. Master thesis, Universiti Kebangsaan Malaysia.

Braide SA, Izonfu WAL, Adiukwu PU, Chindah AC. Obunwo CC. 2004. Water Quality of Miniweja stream, A swamp forest stream receiving Non-point Source Waste Discharges in Eastern Niger Delta Nigeria. Scientific Africans I(1): 1-8.

Charlotte Y. 1998. Applying COSHH Principles to Waste Management. Environmental Health Journal, 106(10) 289 - 291.

Christensen TH, Kjeldsen P, Albrechtsen HJ, Heron G, Nielson PH, Bjerg PL, Holm PE. 1994. Attenuation of Landfill Leachate Pollutants in Aquifers. Critical Reviews in Environmental Science and Technology, 24: 119-202.

Christensen TH, Kjeldsen P, Bjerg PL, Jensen DL, Christensen BJ, Baum A, Albrechtsen HG. 2001. Biogeochemistry of Landfill Leachate Plumes. Applied Geochem., 16: 659-718.

Ehrig HJ. 1989. Leachate Quality in Sanitary Landfilling: Process, Technology and Environmental Impact. Academic Press: London; 20-40.

Fatta D, Papadopoulos A, Loizidou M. 1999. A Study on the Landfill Leachate and Its 
Impact on the Groundwater Quality of the Greater Area. Environment Geochemistry and Health, 21(2):175-190.

Irene MC. 1996. Characteristics and Treatment of Leachates from Domestic Landfills. Environmental International, 22(4): 433-442.

Jhamnani B, Singh SK. 2009. Groundwater Contamination Due To Bhalaswa Landfill Site in New Delhi. International Journal of Environmental Science and Engineering, 1(3):121-125.

Khan FR. 2001. Study of Ground Water Pollution.M.Tech. Thesis. Department of Civil Engineering.University Raipur, India, 6-12.

Longe EO, Balogun MR. 2010. Groundwater Quality Assessment near a Municipal Landfill, Lagos, Nigeria. Research Journal of Applied Science, Engineering and Technology, 2(1): 39-44.

Masood F, Malik A. 2011. Biosorption of Metal Ions from Aqueous Solution and Tannery Effluent by Bacillus sp. Journal of Environmental Science and Health, Part A: Toxic/Hazardous Substances and Environmental Engineering, 46: 166721674

Mor S, Ravindra K, Vischher AR, Dahiya P, Chandra A. 2005. Municipal Solid Waste Characterisation and Its Assessment for Potential Methane Generation at Gazipur Landfill Site, Delhi: A Case Study. Bioresource Technology Communicated.

Moturi MCZ, Rawat M, Subramanian V, 2004. Distribution and Fractionation of Heavy Metals in Solid Waste from Selected Sites in the Industrial Belt of Delhi, India. Environmental Monitoring Assessment, 95: 183-199.
Ojeshina OA. 1999. Sanitary and Hazardous Waste: Landfill as a Waste Disposal Strategy for Nigerian settlement. A paper presented at a one day workshop as part of the activities to mark FEPA's $10^{\text {th }}$ year anniversary: 12 .

Pivato A, Gaspari L. 2005. Acute Toxicity Test of Leachates From Traditional And Sustainable Landfills Using Luminescent Bacteria. Waste Manage., 26: 1148-1155.

Singh A, Chandra S, Kumar Gupta S, Chauhan LK, Kumar Rath S. 2007. Mutagenicity of Leachates From Industrial Solid Wastes Using Salmonella Reverse Mutation Assay. Ecotoxicol Environ Saf. Feb, 66(2): 210-216.

Slomczynka B, Slomczynski T. 2004. Physicochemical and Toxicological Characteristics of Leachates From MSW Landfills. Polish Journal of Environmental Studies, 13(6): 627-637.

Torabian A, Hassani AH, Moshirvaziri S. 2004. Physicochemical and Biological Treatability Studies of Urban Solid Waste Leachate. International Journal of Environmental Science \& Technology, 1(2): 103-107.

Waite R. 1995. Household Waste Recycling. Earthscan Publications Limited: London; 174.

Yoshida M, Ahmed S, Nebil S, Ahmed G, 2002. Characterization of Leachate from Henchir El Yahoudia Close Landfill. Water, Waste and Environment Research, 1(2): 129-142. 